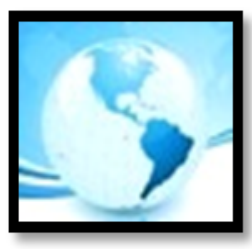

MALAYSIAN ONLINE JOURNAL OF

EDUCATIONAL MANAGEMENT

(MOJEM)

JANUARY 2016, VOLUME 4, ISSUE 1, 32 - 43

E-ISSN NO: $2289-4489$

https://doi.org/10.22452/mojem.vol4no1.3

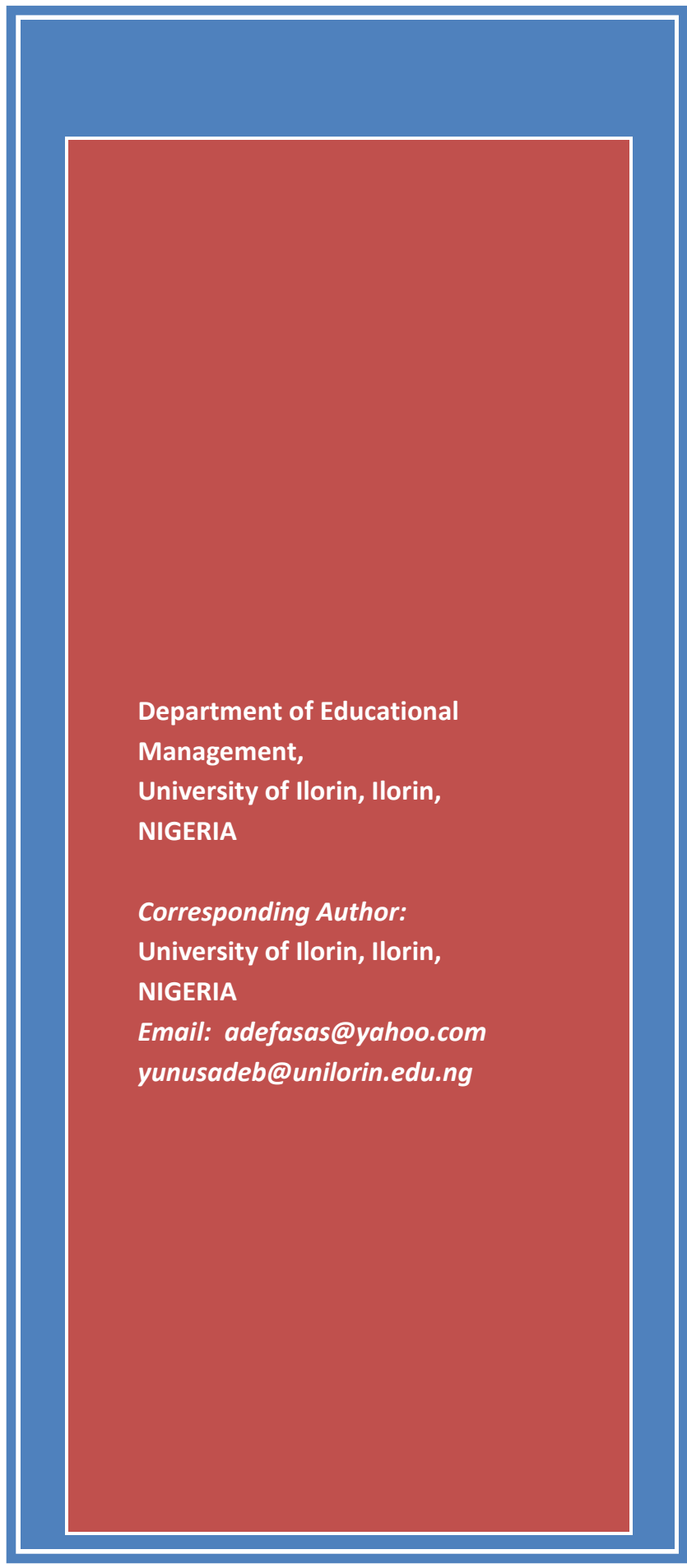

\title{
FACTORS INFLUENCING LECTURERS' MOTIVATION TOWARD MAXIMUM JOB PERFORMANCE IN NIGERIAN HIGHER EDUCATION INSTITUTIONS
}

Fasasi, Yunus Adebunmi (PhD), Etejere P.A.O. \& Oyeniran, Saheed

\begin{abstract}
Managers motivate and induce subordinates to act in desirable ways by doing things which could satisfy their needs. This article examined the factors influencing lecturers' motivation for maximum job performance in higher education institutions in Nigeria. A research instrument titled "Lecturers' Motivation Questionnaire" (LMQ) was adapted from Kwarteng, Obeng-Mensah, and Bosompem (2012) to collect relevant data. Two hundred and forty one (241) lecturers were randomly selected from the sampled higher education institutions. They responded to the instrument which contained eight factors that could influence motivation. The instrument was validated using test-retest reliability method and a reliability coefficient of .7 was obtained. Descriptive and inferential statistics were applied in data analyses. The study showed that job satisfaction, recognition, work condition, supervision and staff involvement in decision-making were the most outstanding factors which could motivate lecturers. Furthermore, lecturers' age and experience were found to influence their motivation. Based on the findings, improvements in motivating factors such as recognition, work condition, supervision and staff involvement in decision-making were recommended.
\end{abstract}

Keywords: Lecturers' Motivation, Job Performance, Higher Education, Nigeria. 


\section{INTRODUCTION}

Motivation is an important factor in education organizations as it enhances staff performance and productivity. In fact, it is crucial in determining the outcome of education. This is because motivated lecturers are more likely to be committed to student educational development and attainment of educational goals. Thus, the lecturers need to be motivated in order to improve their job performance. In most cases, salaries and wages are important motivating factors because they go a long way in satisfying basic needs. If an employee is not motivated, quality of job performance will deteriorate. This assertion was corroborated by Moorhead and Griffin (1998), who stated that employee performance depended on ability and motivation level. Therefore, motivating subordinates to perform to the best of their ability is an important function of educational institution leaders. Motivation could influence an employee's behavior towards achievement of organizational objectives (Bennell \& Akyeampong, 2007). It is a driving force that reinforces an action toward achieving desired objectives (Schater, 2011).

Motivation, according to Fabunmi (2000), emanates from 'motive'. Motivation can be intrinsic (internal) or extrinsic (external). Intrinsic motivation refers to motivation driven by an interest or enjoyment in the task itself, and exists within the individual rather than relying on external pressures or a desire for reward. Intrinsically motivated workers are likely to perform their duties willingly. They are also likely to explore means of improving their skills and capabilities (Wigfield, Guthrie, Tonks, \& Perencevich, 2004). On the other hand, extrinsic motivation refers to activities in the environment which influence an individual to engage in a kind of behavior. It comes from outside of the individual. Rewards in the form of money or grades and threat of punishment as a result of bad behavior are examples of extrinsic motivation. Competition is also an extrinsic motivator because it encourages the performer to win and to beat others, not simply to enjoy the intrinsic rewards of the activity. A cheering crowd and the desire to win a trophy are also extrinsic incentives.

Over the years, scholars have described motivational theories in terms of content and process. Content theorists believe in inner factors that motivate an individual and base their theories on the assumption that individuals have a set of needs which they intend to achieve. The content theorists include McClelland (1965) whose theory is referred to as achievement motivation theory, Maslow (1970) who propounded the hierarchy of needs theory, Alderfer (1972) with his Existence-Relatedness-Growth (ERG) theory and Herzberg (1989) with his two-factor theory. Process theorists such as Adams (1963), Vroom (1964) and Handy (1993) propounded equity and reinforcement theory, expectancy theory and motivational calculus theory, respectively. Ololube (2005) stated further that process theorists focus on how and why people are motivated to achieve organizational goals and emphasize cognitive processes in determining worker motivation. Mawoli and Babandako (2011) investigated staff motivation, dissatisfaction and job performance in an academic setting. A sample of 141 academic staff, representing $64 \%$ of the academic staff population was involved in the study. Descriptive statistics were used in data analysis.

Findings showed that the academic staff was highly motivated at work and they were contented with their working environment. Their performance at teaching was high and they recorded moderate level of performance in research and publication. In the same vein, Kwarteng, Obeng-Mensah, and Bosompem (2012) carried out a study on factors determining motivation of 54 senior high school Agricultural Science teachers in the Central Region of Ghana. The results showed a positive and significant relationship among motivation, work conditions and recognition. Also, a significant relationship was observed between recognition and involvement in goal setting, 


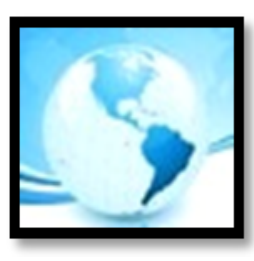

\section{MALAYSIAN ONLINE JOURNAL OF EDUCATIONAL MANAGEMENT (MOJEM)}

recognition and work condition, recognition and supervision. They reported that the best predictors of teacher motivation were recognition and work condition which contribute about $32 \%$ of the variation in teacher motivation. They therefore recommended that various aspects of work condition such as salary, health insurance coverage and accommodation should improve in order to motivate teachers.

Khan and Masood (2013) conducted a study on the relationship between reward and motivation of public sector college teachers in Pakistan. They reported a positive relationship between motivation and pay, job security and working condition. They also found that work itself is the best predictor of motivation. Work itself explains about $34 \%$ variation in motivation while work condition explains $8 \%$ variation in motivation, they stated.

In Nigeria, higher education institutions are also referred to as tertiary education institutions. They constitute the highest level of the Nigerian education system. They include universities, polytechnics, monotechnics, colleges of education and other specialized institutions such as Colleges of agriculture, Schools of Health Technology and National Teachers' Institute (Federal Republic of Nigeria, 2013). In these institutions, the roles of lecturers in providing quality education cannot be over emphasized.

This study was carried out to examine the level of motivation among higher education institution lecturers, the predictors of academic staff motivation and the factors influencing motivation of the lecturers. It also set to determine the relationship between motivation and the motivating factors among the lecturers.

\section{RESEARCH QUESTIONS}

The following research questions were raised:

i. What are the levels of motivational variables among academic staff in Kwara State, Nigeria higher education institutions?

ii. What are the relationships between the academic staff motivation and the motivating factors?

iii. Which of the motivating factors has the greatest potential to motivate academic staff?

iv. What is the influence of demographic factors of academic staff on their ability to be motivated?

\section{METHODOLOGY}

The study adopted a survey research design in order to examine the factors influencing academic staff motivation for maximum job performance in Kwara State, Nigeria higher education institutions. This was to assess the opinions of academic staff about the factors that could motivate them. The population of the study consisted of all lecturers in the 13 higher education institutions in the State. Ten institutions were purposively selected. They consisted of four universities, two polytechnics and four colleges of education. With a representative sample of 241 academic staff, the researchers were able to describe the attitudes of academic staff in Kwara State Nigeria higher education institutions. 
The research instrument used for this study was the "Lecturers' Motivation Questionnaire" (LMQ). This instrument was adapted from Kwarteng et al. (2012) with some modifications to suit the current context. The instrument had three sections. Section A was on demographic information about the respondents, section B was on motivational variables while section $C$ consisted of the independent variables of job satisfaction, supervision, work condition, recognition, promotion, involvement in goal setting and decision making. The instrument variables were specifically based on the content theory of motivation and these were drawn from Herzberg (1989) and Maslow (1970). The respondents were asked to respond to the instrument on a four-point Likert scale ranging from 4 (strongly agree) to 1 (strongly disagree). In order to collect data for this study, 300 copies of questionnaire were distributed; only 241 copies were returned.

The researchers took a number of steps to analyze the data collected. The computed scores were converted to mean level of motivation and motivating factors. The mean ranges from 1.00-2.54 = low, 2.55-3.54 = average, 3.55$4.54=$ high, 4.55-5.00 = very high (Kwarteng et al., 2012). Also, descriptive statistics such as frequencies, percentages, means and standard deviation were used to analyze the data collected. Pearson product moment correlation statistic was used to determine the relationship between motivation and the independent variables of job satisfaction, supervision, work condition, recognition, promotion, involvement in goal setting and decisionmaking at the .05 level of significance. Furthermore, Ordinary Least Square (OLS) was adopted, using multiple regression analysis to determine the best predictors of academic staff motivation at the probability levels of .05 and .10 .

\section{Model Specification}

Multiple regression analysis was used to evaluate the influence of academic staff motivation. In the model, the dependent variable $\mathrm{Y}$ is motivation while the independent variables are: job satisfaction, supervision, work condition, recognition, promotion, involvement in goal setting and decision-making. It is expressed as:

$Y=\beta X+\varepsilon$

The model for academic staff motivation is represented as follows:

$$
\begin{aligned}
& Y=\beta_{0}+\beta_{1}(J B S)+\beta_{2}(S U P)+\beta_{3}(W K C)+\beta_{4}(R C G)+\beta_{5}(P R M)+\beta_{6}(I G S)+\beta_{7}(I D M)+ \\
& \epsilon
\end{aligned}
$$

Where $\mathbf{Y}=$ Motivation, JBS = Job Satisfaction, SUP = Supervision, WKC = Work Condition, $\mathbf{R C G}=$ Recognition, PRM = Promotion, IGS = Involvement in Goal Setting, IDM = Involvement in Decision-Making and $\boldsymbol{\epsilon}_{=\text {error term. }}$ 


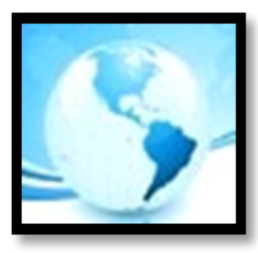

\section{MALAYSIAN ONLINE JOURNAL OF EDUCATIONAL MANAGEMENT (MOJEM)}

In the second stage of analysis, the researchers observed that the demographic characteristics of the respondents influence their ability to be motivated. To this end, another model was formulated to examine the effects of the characteristics. In this model, the dependent variable was motivation while factors such as school type, gender, age, status, area of specialization, qualification, experience were the independent variables. This model is specified as follows:

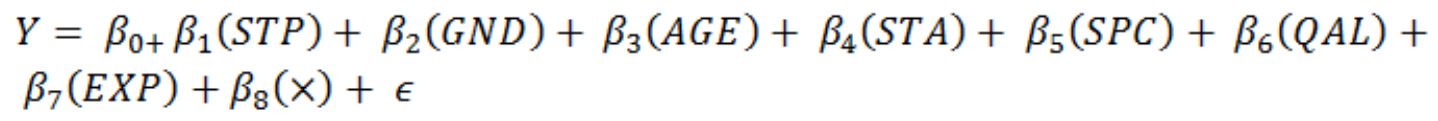

Where $\mathbf{Y}=$ Motivation, STP $=$ School Type, GND = Gender, AGE = Age, STA = Status, SPC = Area of Specialization, $\mathbf{Q A L}=$ Qualification, EXP = Experience, $\mathbf{X}=$ independent variables in (1) and $\boldsymbol{\epsilon}^{=}$error term.

\section{Instrument Reliability and Validity}

In order to determine the instrument reliability, a two-week interval test-retest reliability measurement was carried out. The instrument was administered to 50 academic staff in a higher education institution which was not part of the sample. After two weeks the instrument was administered on the same respondents. The responses from the two administrations were subjected to Pearson correlation analysis. The coefficient of reliability was found to be .7 and this shows that the instrument was reliable. The instrument validity was verified by two experts in the field of measurement and evaluation and educational management. They ascertained content and face validity of the instrument.

\section{RESULTS}

Research Question 1: What are the levels of motivational variables among academic staff in Kwara State, Nigeria higher education institutions?

The following Table 1 gives the mean and standard deviation for the motivation levels according to the different variables. 


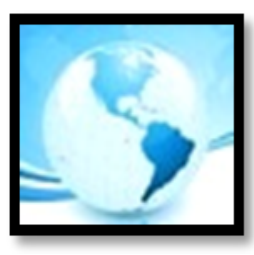

(MOJEM)

Table 1

Levels of Motivational Variables among Academic Staff

\begin{tabular}{llllll}
\hline S/N & Variables & N & Mean & SD & Level of Motivation \\
\hline 1 & Job Satisfaction & 241 & 3.04 & 0.90 & Average \\
2 & Supervision & 241 & 2.95 & 0.92 & Average \\
3 & Work Condition & 241 & 2.79 & 1.16 & Average \\
4 & Recognition & 241 & 3.18 & 0.78 & Average \\
5 & Promotion & 241 & 2.96 & 0.74 & Average \\
6 & Goal Setting & 241 & 2.53 & 1.06 & Average \\
7 & Decision Making & 241 & 3.07 & 0.79 & Average \\
& & & & & \\
\hline
\end{tabular}

Table 1 indicates that the level of motivation ranges from 2.79 to 3.18 and this shows that the level of motivation among the academic staff is average with involvement in goal setting having a low level. This means that the lecturers have not been highly motivated.

Research Question 2: What are the relationships between the academic staff motivation and the motivating factors?

Table 2 gives the correlation between motivation and the motivating factors studied.

Table 2

Relationship between Motivation and Motivating Factors

\begin{tabular}{lllllllll}
\hline & MOT & JBS & SUP & WKC & REC & PRM & GST & DCM \\
\hline MOT & 1 & & & & & & & \\
JBS & .245 & 1 & & & & & \\
SUP & .239 & .234 & 1 & & & & \\
WKC & .174 & .449 & .227 & 1 & & & \\
REC & .212 & .614 & .293 & .548 & 1 & & \\
PRM & .077 & .237 & .269 & .378 & .499 & 1 & & \\
GST & .065 & -.060 & .176 & .112 & -.013 & .175 & 1 & \\
DCM & .189 & .370 & .594 & .446 & .445 & .395 & .211 & 1 \\
& & & & & & & & \\
\hline
\end{tabular}

The findings of this study showed that a positive and significant relationship existed between motivation and the motivating factors: job satisfaction $(r=.245, p<0.05)$, supervision $(r=.239, p<.05)$, work condition $(r=.172, p<$ $.05)$, recognition $(r=.212, p<.05)$, and decision making $(r=.189, p<.05)$ while there was no relationship between motivation and: promotion $(r=.077, p>0.05)$ and goal setting $(r=.065, p>.05)$. 
Table 3

Model Summary

\begin{tabular}{lllcl}
\hline Model & $\boldsymbol{R}$ & $\boldsymbol{R}$ Square & Adjusted $\boldsymbol{R}$ Square & Std. Error of the Estimate \\
\hline 1 & $.249^{\mathrm{a}}$ & .062 & .034 & .65472
\end{tabular}

a. Predictors: (Constant), experience, specialization, status, school type, gender, age, qualification.

As seen in Table 3, the independent variables (predictors) that are entered into the regression model had a combined correlation of $(R=6.2 \%)$ with the dependent variable (motivation). The value of $R$-Squared (the coefficient of determination) is .249, which shows that the independent variables explained $24.9 \%$ of the variance in motivation.

Table 4

ANOVA Table

\begin{tabular}{llllll}
\hline Model & Sum of Squares & Df & Mean Square & $\boldsymbol{F}$ & Sig \\
\hline Regression & 6.593 & 7 & .942 & 2.197 & $0.35^{\mathrm{b}}$ \\
Residual & 99.448 & 232 & .429 & & \\
Total & 106.041 & 239 & & & \\
& & & & &
\end{tabular}

a. Dependent Variable: Motivation

b. Predictors (Constant): experience, specialization, status, school type, gender, age, qualification.

The ANOVA analysis (Table 4) showed the F-value of 2.197 was significant at the .035 level. It means that the above model is fit, that is there is a significant relationship between independent variables and the dependent variable. Hence the regression analysis also validates the research question as four of the independent variables were found to be significant at the .05 level.

Research Question 3: Which of the motivating factors has the greatest potential to motivate academic staff?

Table 5 displays the beta and $t$ values as well as the significance of $t$ for the variables examined. 
Table 5

Predictors of Lecturer's Motivation

\begin{tabular}{lllll}
\hline $\mathbf{S} / \mathbf{N}$ & Variable & Beta & $\boldsymbol{t}$ & Sig \\
\hline 1 & & & & \\
2 & Job Satisfaction & .240 & 1.645 & .002 \\
3 & Supervision & .189 & 2.343 & .020 \\
4 & Work Condition & .235 & .432 & .003 \\
5 & Recognition & .368 & .703 & .003 \\
6 & Promotion & -.067 & -.874 & .383 \\
7 & Goal Setting & -.017 & -.188 & .851 \\
& Decision Making & .314 & .604 & .021 \\
\hline
\end{tabular}

Referring to Table 5, job satisfaction, work condition, recognition and involvement in decision-making were found to be the predictors of academic staff motivation in Kwara State higher education institutions with recognition contributing $36.8 \%$, involvement in decision- making $31.4 \%$, job satisfaction $24.0 \%$ and work condition $23.5 \%$.

Table 6

Factors Influencing Lecturers' Motivation

\begin{tabular}{lllll}
\hline S/N & Variable & Beta & $\boldsymbol{t}$ & Sig \\
\hline 1 & School Type & -.003 & -.037 & .970 \\
2 & Gender & .095 & 1.293 & .197 \\
3 & Age & .420 & .239 & .001 \\
4 & Status & .049 & .695 & .488 \\
5 & Specialization & .135 & 1.758 & .080 \\
6 & Qualification & .187 & 1.957 & .052 \\
7 & Experience & .233 & .136 & .002 \\
8 & Supervision & .253 & 2.863 & .005 \\
& & & & \\
\hline
\end{tabular}

In order to determine the factors influencing academic staff motivation, the effects of demographic characteristics of the respondents on motivation was controlled. It was discovered that academic staff age and experience are the two major factors influencing academic staff motivation. Academic staff age was shown to have the greatest potential to influence academic staff motivation, contributing about $42 \%$ influence while experience contributes about $23.3 \%$. This shows the effects of age and experience on motivation. 


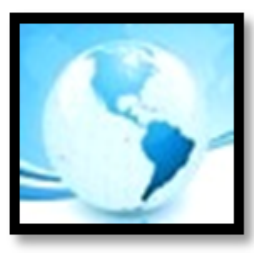

Research Question 4: What is the influence of demographic factors of academic staff on their ability to be motivated?

The following Table 7 shows the demographic characteristics of respondents in this study.

Table 7

Characteristics of the Respondents

\begin{tabular}{|c|c|c|c|}
\hline Variable & Classification & Frequency (F) & Percentage (\%) \\
\hline \multirow[t]{2}{*}{ School Type } & Private & 35 & 14.5 \\
\hline & Public & 206 & 85.5 \\
\hline \multirow[t]{2}{*}{ Gender } & Male & 133 & 55 \\
\hline & Female & 108 & 45 \\
\hline \multirow[t]{4}{*}{ Age } & $20-30$ & 85 & 35.3 \\
\hline & $31-40$ & 74 & 30.7 \\
\hline & $41-50$ & 56 & 23.2 \\
\hline & 51 and above & 26 & 10.8 \\
\hline \multirow[t]{4}{*}{ Area of Specialization } & Science & 41 & 17 \\
\hline & Social Science & 90 & 37.3 \\
\hline & Engr/Tech & 66 & 27.4 \\
\hline & Humanities & 44 & 18.1 \\
\hline \multirow[t]{3}{*}{ Qualification } & Bachelor Degree & 77 & 32 \\
\hline & Master Degree & 120 & 49.8 \\
\hline & Doctoral Degree & 44 & 18.3 \\
\hline \multirow[t]{5}{*}{ Experience } & $1-5$ yrs & 100 & 41.5 \\
\hline & $6-10$ yrs & 65 & 27 \\
\hline & $11-15$ yrs & 29 & 12 \\
\hline & $16-20$ yrs & 31 & 12.9 \\
\hline & 21 and above & 16 & 6.6 \\
\hline
\end{tabular}

Table 7 shows that $85.5 \%$ of the academic staff in the sample were from public institutions and only $14.5 \%$ were from private institutions. There were more male (55\%) academic staff than females (45\%). The academic staff aged 40 years and below represented $66 \%$ of the sample. In areas of specialization, academic staff specializing in Social Sciences formed the highest percentage (37.3\%). On the basis of qualification, $49.8 \%$ had a Master degree. The academic staff with 10 years' experience and below represented $68.5 \%$. 


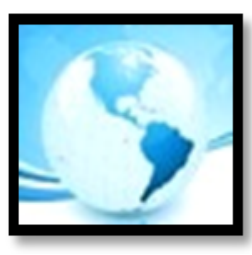

\section{MALAYSIAN ONLINE JOURNAL OF EDUCATIONAL MANAGEMENT (MOJEM)}

\section{DISCUSSION OF FINDINGS}

The findings indicated that, on average, variables such as job satisfaction, supervision, work condition, recognition, promotion and involvement in decision-making can impact on academic staff motivation if they are given attention by heads of the institutions. This will boost the lecturers' morale and enhance their work performance. The findings of Ololube (2005) and Nbina (2010) which stated that providing good and reasonable salary and improved work condition will enhance teacher motivation, were in line with this finding. The low level of motivation observed for involvement in goal setting however, could be because very few academic staff were allowed to participate in organizational goal setting.

The study also found a positive and significant relationship between motivation and job satisfaction, supervision, work condition, recognition and involvement in decision-making. These are motivating factors which, if improved upon, will enhance academic staff performance. It must be noted that the extent to which these factors are provided will to a greater extent improve staff motivation. Kwarteng et al. (2012) reported that positive and significant relationship exists between motivation and work condition, recognition, supervision and job satisfaction. In this study, promotion and involvement in goal setting did not show any relationship with motivation. This might be because most academic staff did not see promotion as a motivating factor. In the same vein, involvement in goal setting is a management issue where many academic staff were not involved and as such is not a motivator for them.

The predictor of academic staff motivation was found to be job satisfaction, work condition, recognition and involvement in decision-making. Furthermore, recognition was found to be the most important predictor of academic staff motivation as it contributes about $36.8 \%$ to their motivation. Also, involvement in decision-making contributed about $31.4 \%$ while job satisfaction and work condition were found to contribute $24 \%$ and $23.5 \%$ respectively. This implies that when academic staff receives verbal and tangible recognition for good performance, and if their achievements are acknowledged and given material reward as appreciation for desirable job performance, they are likely to be motivated. They will develop a sense of belonging; feel recognized and would be ready to contribute their best to achieving institutional goals.

This study found that age and experience were the most important factors influencing academic staff motivation. Age was found to be the most important factor with a contribution of $46 \%$ while experience has an influence of 23.3\%. At a younger age (between $20-40$ years), workers tend be healthy, fresh, have high expectation and hopeful of good condition of service. These motivate them and enhance their performance. But when they become older, these tend to diminish and may no longer serve as motivators.

\section{CONCLUSION}

Motivation is an important aspect of teacher management. The extent of teacher motivation will greatly impact on productivity which will enhance achievement of educational goals in Nigeria. This research has shown that academic staff recognition, work condition, job satisfaction, supervision and involvement in decision- making are important determinants of teacher motivation. Various activities of academic staff towards achieving the organizational objectives must be recognized when due. Improved work condition, adoption of modern approach to supervision and staff involvement in decision-making will boost their morale, and serve as motivators. This 


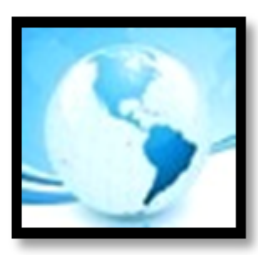

\section{MALAYSIAN ONLINE JOURNAL OF EDUCATIONAL MANAGEMENT (MOJEM)}

eventually will enhance academic staff performance. Administrators of higher education institutions should understand human beings as social animals who need to be motivated in order to contribute to the organization's success.

\section{RECOMMENDATIONS}

Based on the findings of this study, the following recommendations were made:

1 There is need for improving the motivating factors such as recognition, work condition, supervision and staff involvement in decision-making. These have been found to be motivators and administrators must understand and always improve on them.

2. Academic staff motivation must be part of day-to-day administration. Administrators must realize that it is only when this is done that the organizational objectives can be achieved.

3. Administrators should not always wait for workers' unions to embark on industrial action before putting in place motivational packages and strategies.

4. Age is an important factor influencing teacher motivation; therefore, in the process of teacher recruitment exercise, priority should be in favor of younger graduates.

\section{REFERENCES}

Adams, J. S. (1963). Towards an understanding of inequity. Journal of Abnormal and Social Psychology, 67, 422436.

Alderfer, P. C. (1972). Existence, relatedness and growth: Human needs in organizational settings. New York, NY: The Free Press.

Bennell, P., \& Akyeampong, K. (2007). Teacher motivation and incentives in Sub-sahara Africa and Asia. Educational paper: Centre for International Development. Retrieved from https://www.gov.uk/government/organisations/department-for-international- development.edu

Fabunmi, M. (2000). Management and motivation. Ibadan, Nigeria: Odun prints.

Federal Republic of Nigeria. (2013). National policy on education. Lagos, Nigeria: NERDC.

Herzberg, F. (1989). One more time: How do you motivate employees? In O. Steven (Ed.),Classic readings in organizational behavior. Pacific Grove, CA, Brooks/Cole

Handy, C. (1993). Understanding organizations (4th ed.). New York, NY: Penguin. 


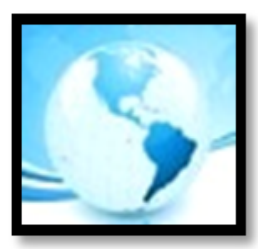

\section{MALAYSIAN ONLINE JOURNAL OF EDUCATIONAL MANAGEMENT (MOJEM)}

Khan, M. M., \& Masood, H. T. (2013). Conceptualizing motivational factors of educationists.Journal of Business and Management Research, 2(2), 88- 98.

Kwarteng, J. A., Obeng-Mensah, A., \& Bosompem, M. (2012). Determinants of motivation of senior high school agricultural science teachers in the central region of Ghana. Journal of Arts, Science and Commerce, 3(1), $106-114$.

Maslow, A. H. (1970). Motivation and personality (2nd ed.). New York, NY: Harper \& Row.

Mawoli, M. A., \& Babandako, A. Y. (2011). An evaluation of staff motivation, dissatisfaction and job performance in an academic setting. Australian Journal of Business and Management Research, 1(9), 1-13.

McClelland, C. D. (1965). Achievement motivation can be developed. Harvard Business Review, 43(6), 6-24.

Moorhead, G., \& Griffin, R. W. (1998). Organizational behavior: Managing people and organizations (5th ed.). Boston, MA: Houghton Mifflin.

Nbina, J. B. (2010). Re-visiting secondary school science motivation strategies to face the challenges in the 21st century. New York Science Journal, 3(12), 15-20.

Ololube, N. P. (2005). Benchmarking the motivational competencies of academically qualified researchers and professionally qualified teachers in Nigerian secondary schools. The African Symposium, 5(3), 17-37. Retrieved from: https//www.ncsu.edu/aern/archives.htm

Schater, D. (2011). Psychology. New York, NY: Catherine Woods.

Vroom, V. H. (1964). Work and motivation. New York, NY: Wiley.

Wigfield, A. Guthrie, J. T., Tonks, S., \& Perencevich, K. C. (2004). Children's motivation for reading: Domain specificity and instructional influences. Journal of Educational Research, 97, 299-309. 